\title{
FARMING DEVELOPMENT STRATEGY IN COCONUT IN POHUWATO REGENCY
}

\author{
Amran Gaga *1) \\ 1) Expert Economic of House Representatif, Pohuwato Regency, Gorontalo, Indonesia \\ *) Corresponding Author E-mail: amrangaga87@gmail.com
}

\begin{abstract}
The purpose of this study were: 1) Analyzes the factors that influence the development of coconut cultivation in Pohuwato; 2) Coconut farming development strategy in Kabuoaten Pohuwato.The study was conducted in Pohuwato of the month December 2019 until February 2020 with a sample of 40 farmers. The method used is a survey method possible. Analysis of the data used is analysis SWOT. The results showed that the factors that influence the development of coconut in Pohuwato namely internal and external factors that influence the development strategy of the Coconut Pohuwato that internal factors are replaced plant coconut, oil prices often fluctuate, the lack of rejuvenation of coconut plantations and processing farms palm are still traditional. While external factors are unpredictable weather conditions which cause crop failure, there is no pricing dassar coconut and coconut farmers besides farming. The development strategy of coconut in Pohuwato which is located in Quadrant I, which supports the strategy Aggressive or S-O strategy (strenght opportunity) by using the strength of such experience or the ability of farmers, as well as take advantage of existing opportunities such as coconut plants have good market prospect, to minimize weakness as oil prices frequently fluctuate, then the existing threats as there is no basic pricing oil and erratic climate conditions so that the development of coconut cultivation achieve progress.
\end{abstract}

Keywords: coconut oil; development strategy; SWOT analysis.

\section{INTRODUCTION}

Coconut plant has wide adaptability. Coconut usability very much, the entire plant can be used, so it is known as a multi-purpose plant. Data in 2019 shows, Indonesia has a coconut area of 3,500,726 ha., and produces production of 2,992,190 tons (Indonesia Center for Estate Crops Research and Development, 2020). Based on the data, coconut commodities are important in the Indonesian economy and have great potential as foreign exchange producers through exports. There are some results of the commodity in Indonesia is known worldwide, such as copra. Copra or dried coconut meat is raw material for crude coconut oil (CCO) and other derivative products (Tompodung et al., 2016).

Gorontalo province has potential plantation land area is quite large, scattered in various districts. Based on data from the Directorate General of Plantations in 2017, the total land area of coconut plantations Gorontalo Province reached 73260 ha, with the average number of productivity per year is 56179 tonnes. The number of coconut farmers in Gorontalo Province in 2017 reached 55878 people who followed a total of 1,334 person workforce. Based on these data can be seen a considerable gap between the number of coconut farmers and the amount of labor, so they are also an impact on productivity figures, (BPS Pohuwato, 2015). 
Pohuwato is one of the districts in the province of Gorontalo. The district capital Pohuwato is Marisa, Pohuwato is about $165 \mathrm{~km}$ from the provincial capital of Gorontalo city of Gorontalo. Pohuwato tree crop production consists of coconut, corn, cocoa, patchouli, and chili. The production plant is the largest in Pohuwato coconut copra is the raw material commodities. Pohuwato has an area of 16821 hectares which is smallholder or an estate that is processed by the people to meet the needs of households and can be seen that the coconut plantation production reached 27.936.12 tons (BPS Pohuwato, 2015).

The purpose of this study is analyzes internal and external factors that influence the development of coconut cultivation in Pohuwato regency, and formulating a strategy for developing coconut farming in Pohuwato regency.

\section{METHOD}

The research location is taken deliberately or purposive, the location chosen is Pohuwato consideration that Pohuwato have farmers who started to develop coconut plants. This study will be conducted over 3 months are December 2019 to February 2020. The method used is a survey method which is the collection of empirical data based on interviews and observations. Types and sources of data in this study are primary data and secondary data. Coconut farmers mastery land area is varied, then the sample is determined by purposive sampling system based on broad palm. Due to the number of population at the site of 250 farmers, the total population is taken $15 \%$ of the 250 farmers that the number of sample of 40 farmers. According to Arikunto (2010) if the subject is less than 100 better taken all until the research is population research. Furthermore, if the number of large subjects can be taken 10-15 percent or more depending on at least the ability of the researcher seen from time, effort, and cost. Data collected by observation, questionnaires, interviews and documentation. The analytical method used in research is SWOT analysis.

SWOT techniques analyze the strengths, weaknesses, opportunities and threats faced by the company so as to formulate appropriate development strategies. According to Rangkuti (2009) "This SWOT analysis was created by comparing between external factors of opportunity and threat with internal factors of strengths and weaknesses". SWOT analysis required matrix of external strategy factors (EFS) and internal strategy factors (IFS). From the matrix analysis of the strategy factors, strategy management can find out what strategic factors it has and what can be done (Thoyib, 2005), especially to develop coconut plants.

\section{RESULTS AND DISCUSSION}

\section{A. Internal Factors Coconut Development}

1. Strength Factor Coconut Development

a) Increased Oil Production

With the success of the oil in Pohuwato developed so that it becomes a superior product and can increase household incomes.

b) Farmers experience in utilization and development of coconut farming Knowledge of coconut farmers who have been smart enough and experienced in using and developing the coconut farming enabled farmers to develop farming it self.

c) Favorable Farmer Household Income Coconut oil can be beneficial to farmers because it is one of the products that become staples in almost every food.

d) Utilization of coconut plants

Coconut plant is very beneficial to the community from the roots to the leaves to meet household needs and for building houses or buildings. 
e) Low maintenance costs

Coconut plant does not require production inputs are much like other plants.

f) High Number of Requests

The demand amount increasing oil commodity at any time since coconuts are very important in any food or beverage is made. Oil demand not only from consumers who are in the household, but also from companies with coconut require to be made into processed materials.

2. Weakness Factors Coconut Development

a) Crop substitution coconut

The existence of substitute crops namely coconut cooking oil that is made from palm oil.

b) Oil prices often fluctuate

Copra prices in marketing determined by the world market.

c) Lack of replanting coconut

Farmers more dominant farming maize, chili and coconut berusahan dibangdingkan horticulture.

d) That Still Traditional Farming Processing

Farmers in their farming Pohuwato process manually or traditional still using sophisticated tools for high cost of equipment or technology and limited capital Coconut farmers develop farming.

\section{B. External Factors Coconut Development}

1. Opportunities Factors Coconut Development

a) Good market prospects

Coconut plants in Pohuwato have a good market prospect in addition to the use as consumption can also be used as a building material needs of housing, due to government restrictions on logging, coconut wood be good alternatives. Coconut plants still have good market prospects, especially derivatives, among others : nata de coco, pungkil coconut, coconut oil, VCO, coconut water, coconut milk, stick palm, coconut fiber, and others.

b) The needs of the automotive industry

The need for the automotive industry such as car seat use and utilizes coconut fiber instead of rubber belt made from increasingly expensive.

c) Online marketing

Their online marketing that can be utilized to serve as a medium of information on oil derivatives product that costs more efficient production.

d) Their cooperation Farmers Large Enterprises

Utilization and development of coconut farming is done by farmers in the district apparently attracted the attention of major companies such as PT. Multi Vegetable Sulawesi to work with farmers to sell their products and provide assistance and training to farmers in the manage and develop farming.

e) Increased Demand coconut

The increasing demand for palm oil creates the opportunity for farmers in Pohuwato to keep harness and develop farming. Many consumer demand for basic commodities, especially oil in the face of the holy month and the days of the other so that makes oil demand increases.

2. Threats Factors Coconut Development

a) There Is No Basis Oil Pricing

The absence of basic pricing coconut into one of the threats that must be faced by farmers. The fall in oil prices suddenly could cause harm to farmers in farming, it should be anticipated that farmers will not lose. 
b) Weather Conditions Makers

Unpredictable weather conditions cause the coconut farmers in Pohuwato experienced a reduction in the number of production produced. Climate change where the dry season over a longer period when compared to the rainy season, causing many oil plants were dead and the life of his product was on the wane.

c) Farming besides coconut plant

Coconut farmers prefer other farming as corn farming has been secured marketing and price so that the plant is not considered again by the coconut farmers.

\section{Coconut Farm Development Strategy in Pohuwato}

In goal setting and identifying good and beneficial internal and external factors, SWOT Analysis is used to compare internal and external factors (Rangkuti, 2009).

Table 1. Internal Analysis Coconut Development Strategy

\begin{tabular}{clccc}
\hline No. & Internal factors & Weight & rating & Score \\
\hline & Strengths (Strengths) & 0.07 & 2 & 0.14 \\
2 & Increased Oil Production & 0.10 & 3 & 0.3 \\
2 & Farmers experience in utilization and Coconut Farm & 0.15 & 4 & 0.6 \\
3 & Development & 0.15 & 4 & 0.6 \\
4 & Profitable Revenue Farmer Households. & 0.13 & 3 & 0.39 \\
5 & Ltilization of oil plants & 0.05 & 2 & 0.1 \\
6 & The high number of requests & $\mathbf{0 . 6 5}$ & & $\mathbf{2 . 1 3}$ \\
\hline & Total strengths & & & \\
& Weakness (Weakneses) & 0.10 & 1 & 0.1 \\
1 & Crop substitution coconut & 0.05 & 2 & 0.1 \\
2 & Oil prices often fluctuate & 0.10 & 1 & 0.1 \\
3 & Lack of replanting coconut & 0.10 & 1 & 0.1 \\
4 & Traditional farming still processing & $\mathbf{0 . 3 5}$ & & $\mathbf{0 . 4}$ \\
\hline & Total weakness Total & & $\mathbf{1 . 7 3}$ \\
\hline
\end{tabular}

Source: Data processed, 2020

Table 2. External Analysis Coconut Development Strategy

\begin{tabular}{clccc}
\hline No. & External factors & Weight & rating & Score \\
\hline & Opportunity (Opportunity) & 0.15 & 4 & 0.6 \\
1 & Good market prospects & 0.15 & 4 & 0.6 \\
2 & The needs of the automotive industry & 0.12 & 3 & 0.36 \\
3 & Pemsaran online & 0.10 & 3 & 0.3 \\
4 & Their cooperation Farmers Large Companies & 0.11 & 3 & 0.33 \\
5 & Increased Demand coconut & $\mathbf{0 . 6 3}$ & & $\mathbf{2 . 1 9}$ \\
\hline & Total Opportunities & 0.13 & 1 & 0.13 \\
\hline & Threats (Threaths) & 0.13 & 1 & 0.13 \\
2 & Pricing basis There Is No Oil & 0.11 & 2 & 0.22 \\
3 & WEATHER CONDITIONS Makers & $\mathbf{0 . 3 7}$ & & $\mathbf{0 . 4 8}$ \\
\hline & Farming besides coconut plant & & & $\mathbf{1 . 7 1}$ \\
\hline
\end{tabular}

Source: Data processed, 2020

To find coconut farming development strategy in Pohuwato regency using SWOT analysis diagram can be seen in the Figure 1. Based on the Figure 1, it is known that the strength of greater than weaknesses, so as to produce the X-axis of the diagram SWOT analysis, thus facing greater opportunities than threats resulting $\mathrm{Y}$-axis of the diagram SWOT analysis. The difference between the figures show the strengths and weaknesses of 1.73 , Table 1 (value derived from the value of the total power less the value of total weakness). While the difference of opportunities and threats is 1.71, Table 2 (value derived from the value of total chances minus total threats). Then coconut farming development strategy in Pohuwato regency are in quadrant I, which supports an 
aggressive strategy or strategies S-O (Strenghts-Opportunities). This shows that the strategy of development of coconut farming Pohuwato have the power and opportunity to minimize the weaknesses and threats that exist in Pohuwato regency.

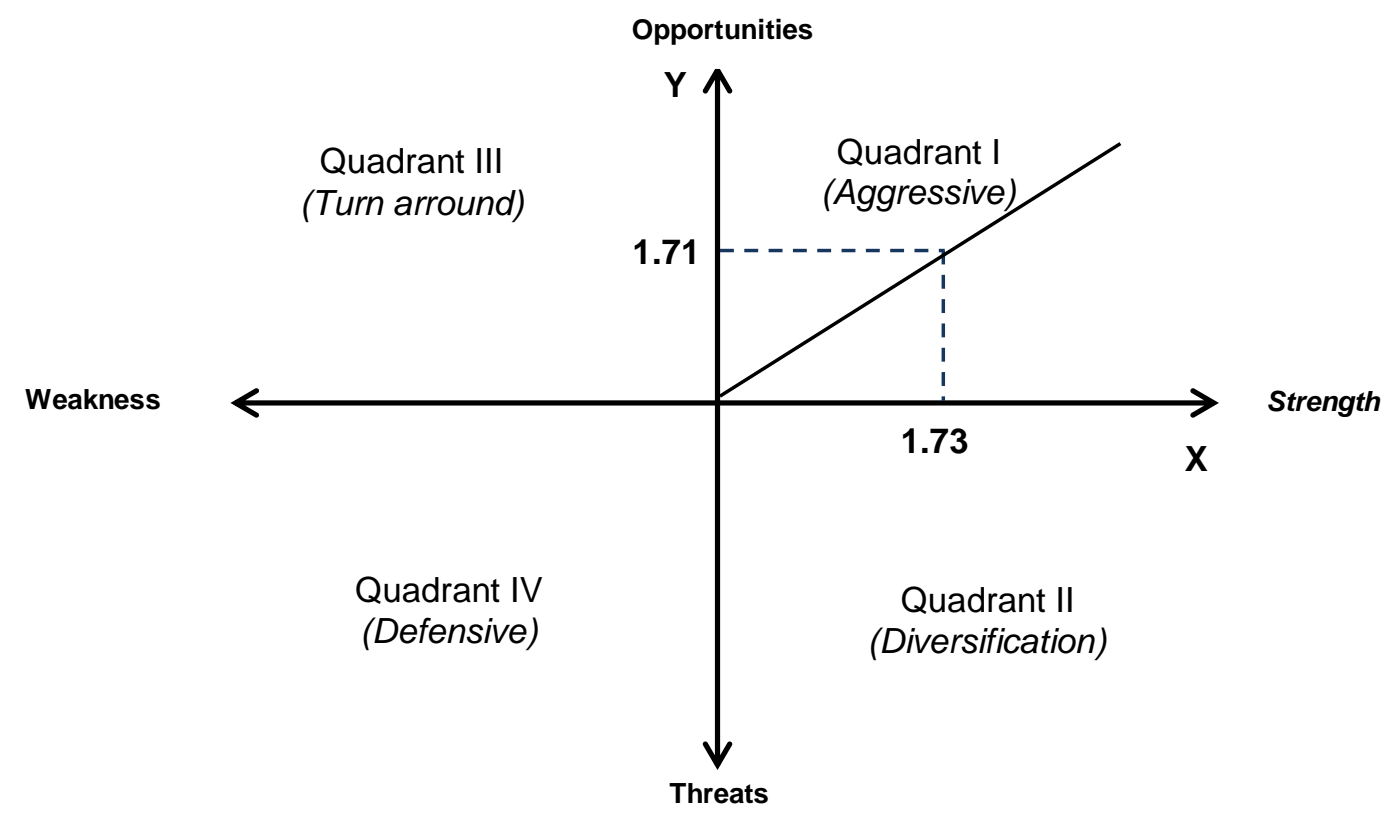

Figure 1. SWOT Analysis Coconut Farm Development Strategy in Pohuwato Regency

\section{Coconut Farm Development Matrix in Pohuwato Regency}

SWOT matrix illustrates how management can match external opportunities and threats faced by its internal strengths and weaknesses. This can be seen in the following Table 3.

Table 3. SWOT Matrix Internal and External Environment

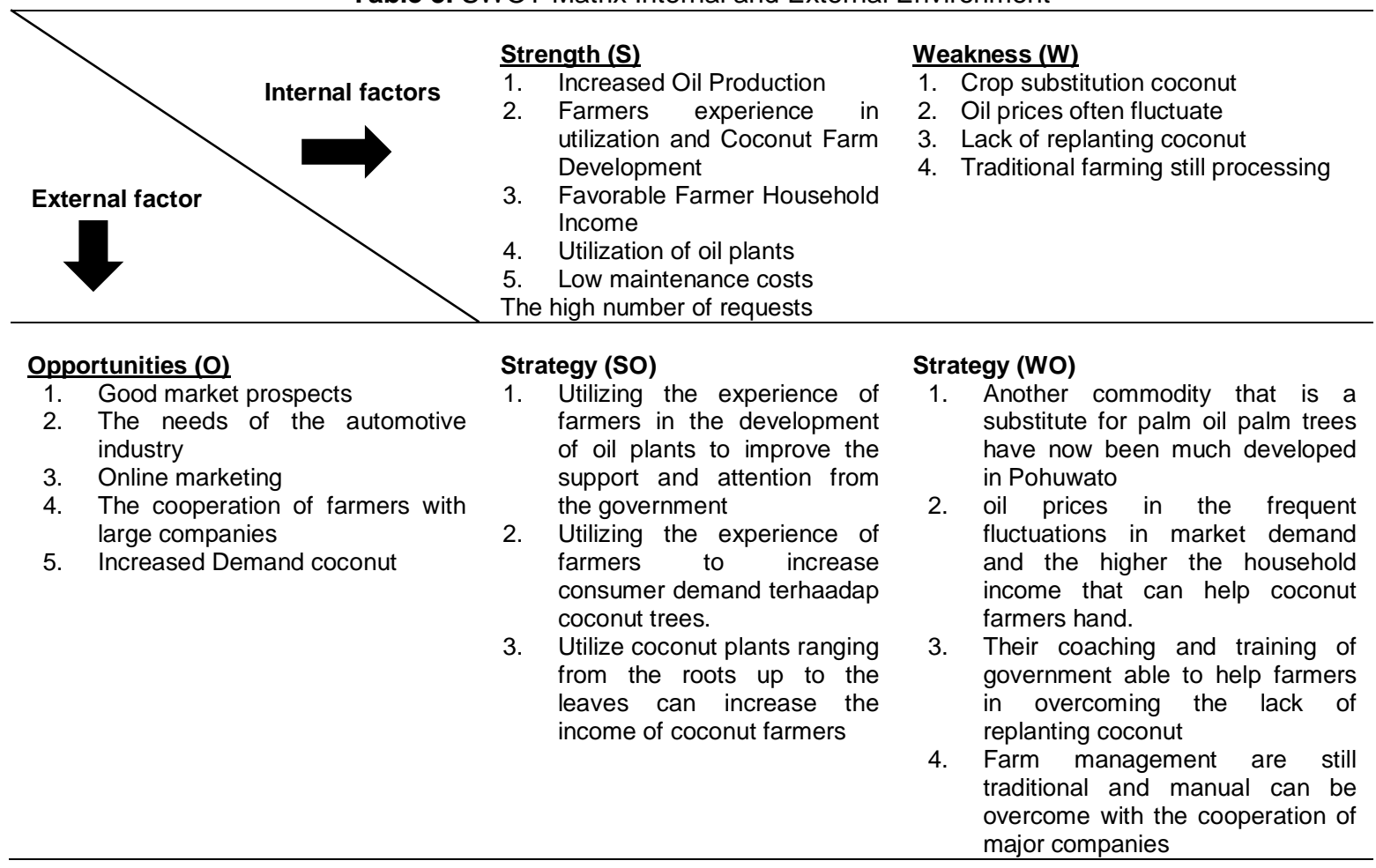




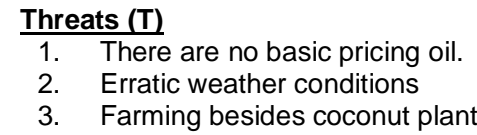

Source: Data processed, 2020
Strategy (ST)

1. The experience of farmers in the development of coconut farming can troubleshoot crop failure caused by erratic weather conditions

2. With the high number of requests of farmers should know the price or information about the coconut in the market to minimize the price in the marketing game.

3. By utilizing the coconut crop in from the roots up to the leaves can cause other farmers will not be farming.

\section{Strategy (WT)}

1. Prevent the high risk of crop failure by addressing problems erratic weather conditions that interfere with palm cultivation.

2. Increase the knowledge of farmers on the price information available in the market to minimize their game market price.

3. Improving the processing of oil plants in the well so that the plants do not take the role of a substitute for palm plantations in.

4. Increase replanting coconut palm plantations in order to issue the replacement will not occur.

\section{CONCLUSION}

Internal and external factors that influence the development strategy of the Coconut Pohuwato that internal factors are replaced plant coconut, oil prices often fluctuate, lack of replanting coconut, coconut farming and processing are still traditional. While external factors are unpredictable weather conditions which cause crop failure, there is no pricing dassar coconut and coconut farmers besides farming.

The development strategy of coconut in Pohuwato which is located in Quadrant I, which supports the strategy Aggressive or S-O strategy (strenght - opportunity) by using the strength of such experience or the ability of farmers, as well as take advantage of existing opportunities such as coconut plants have good market prospect, to minimize weakness as oil prices frequently fluctuate, then the existing threats as there is no basic pricing oil and erratic climate conditions so that the development of coconut cultivation achieve progress.

\section{REFERENCES}

Arikunto, S. 2010. Prosedur Penelitian Suatu Pendekatan Praktik. Jakarta: Rineka Cipta.

BPS Pohuwato 2015. In Figures Gorontalo province.

Indonesia Center for Estate Crops Research and Development. 2020. Strategi Pengembangan Kelapa Nasional Dan Tantangannya. Accessed, April 2020. < http://perkebunan.litbang.pertanian.go.id/strategi-pengembangan-kelapa-nasionaldan-tantangannya/>

Rangkuti. Freddy. 2009. SWOT Analysis Techniques Dissecting the Business Case. Jakarta. Gramedia Pustaka Utama

Thoyib, Armanu. 2005. Hubungan Kepemimpinan, Budaya, Strategi, dan Kinerja: Pendekatan Konsep. Jurnal Manajemen dan Kewirausahaan, 7(1), 60-73

Tompodung, R. L., Lapian, J., \& Van Rate, P. 2016. Analisis Rantai Pasokan Pada Komoditas Kopra Di Desa Elusan Kabupaten Minahasa Selatan. Jurnal EMBA: Jurnal Riset Ekonomi, Manajemen, Bisnis dan Akuntansi, 4(3). 246-255 